The Other Side of Profound Handicap 
Patients are people. They have feelings, families and fears. Whatever the cause for their seeking help, the caring professional will find that he or she will be concerned with these other issues. All illness carries with it anxiety and each person has very individual and important feelings about it; feelings which can easily be forgotten or neglected when nurses become preoccupied with the details of treatments, procedures and ward routines.

The New Approaches to Care series aims to explore this 'other side' of care in a practical and realistic way, emphasising the importance of meeting all the patients' needs, while recognising the constraints and problems which so often make the "other side the forgotten side of patient care.

The books in this series examine the implications that treatments, procedures, investigations and routines can have for patients and their families. They also aim to help nurses gain some insight into the problems, feelings and anxieties which people can experience when they are being looked after in hospital or the community. The series will thus offer a tangible starting point for all nurses and other professionals, both in training and in practice, to give their patients the most complete and understanding care possible.

\section{Series Editors}

June Jolly, SRN, RSCN, has devoted most of her nursing career to the care of sick children, and was involved with establishing a new paediatric unit at Brook General Hospital, Woolwich.

Jill Macleod Clark, BSc, $\mathrm{PhD}, \mathrm{SRN}$, is a Lecturer in the Department of Nursing Studies, Chelsea College, University of London.

Will Bridge, $\mathrm{BSc}, \mathrm{PhD}$, is the Co-ordinator of the Learning Resources Unit at Brighton Polytechnic. 
Other titles in this series

The Other Side of Growing Older Pat Brown

The Other Side of Paediatrics June Jolly

The Other Side of Psychiatric Care Margaret Garland

The Other Side of Surgery Janet Gooch

The Other Side of Medical Care Carol Flemming 


\section{Heaven's Very Special Child}

A meeting was held quite far from earth 'It's time again for another birth' Said the angels to the Lord above 'This special child will need much love

His progress may seem very slow Accomplishments he may not show And he'll require extra care From the folks he meets down there

He may not run, or laugh or play His thoughts may seem so far away In many ways he won't adapt And he'll be known as handicapped

So let's be careful where he's sent We want his life to be content Please Lord, find parents who Will do a special job for you

They will not realise right away The leading role they're asked to play But with this child sent from above Comes stronger faith and richer love And soon they'll know the privilege given In caring for this gift from Heaven This precious child, so meek and mild Is Heaven's Very Special Child.'

Anon.

For my friends in Harrow, all of whom are very special 


\title{
THE OTHER SIDE OF PROFOUND HANDICAP
}

\author{
Pat Brudenell \\ RMN, RDTh, DipDTh, AIST, Cert Ed
}

Photographs by

John Crowson

Front Cover by

Gillian Simmonds

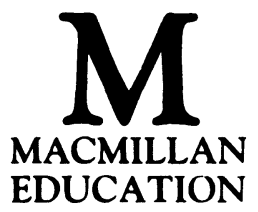


All rights reserved. No reproduction, copy or transmission of this publication may be made without written permission.

No paragraph of this publication may be reproduced, copied or transmitted save with written permission or in accordance with the provisions of the Copyright Act 1956 (as amended), or under the terms of any licence permitting limited copying issued by the Copyright Licensing Agency, 7 Ridgmount Street, London WC1E 7AE.

Any person who does any unauthorised act in relation to this publication may be liable to criminal prosecution and civil claims for damages.

First published 1986

Reprinted 1987

Published by

MACMILLAN EDUCATION LTD

Houndmills, Basingstoke, Hampshire RG21 2XS

and London

Companies and representatives

throughout the world

British Library Cataloguing in Publication Data

Brudenell, Pat

The other side of profound handicap.-(New

approaches to care)

1. Mentally handicapped-Care and treatment

I. Title II. Series

$362.3^{\prime} 8$ HV3004

ISBN 978-0-333-41812-3

ISBN 978-1-349-18305-0 (eBook)

DOI 10.1007/978-1-349-18305-0 


\section{Contents}

Epigraph

iv

Foreword Sue Jennings xiii

Preface

Acknowledgements

XV

xvii

1 Looking at Handicap From All Sides 1

Looking at society 1

Introduction 1

Handicap in the Middle Ages $\quad 3$

Historical background 4

Looking at the family 6

Pregnancy 6

When the baby is born $\quad 8$

After the baby is born $\quad 10$

The formative years 14

One-way communication channels $\quad 15$

$\begin{array}{ll}\text { Socially } & 17\end{array}$

What happens after I'm gone? 18

Looking at the child $\quad 19$

$\begin{array}{ll}\text { Boundaries } & 19\end{array}$

Adult-based childhood 19

Physical restrictions $\quad 20$

Exploration and creativity $\quad 20$

Not great expectations $\quad 22$

The Peter Pan syndrome $\quad 23$

Looking at the staff 24

Who cares? 24

The isolation of Special Care Units 25

The professionals 26

Models $\quad 26$ 
viii Contents

$\begin{array}{ll}\text { Training } & 28\end{array}$

In-service training $\quad 28$

Without training $\quad 29$

Time out $\quad 29$

Who cares about the people who care? 30

Supervision $\quad 32$

2 Fighting Handicap: Looking More Closely at Some of the Problems

Transference $\quad 35$

Being helpless $\quad 36$

Fear $\quad 39$

Can't stop now $\quad 40$

The battling syndrome $\quad 40$

Campaigning or complaining? 42

What problems? $\quad 43$

Trust 44

Parental trust $\quad 45$

Aggression $\quad 48$

Language $\quad 54$

3 Complicating Handicap $\quad 58$

It's got nothing to do with handicap $\quad 58$

Depression $\quad 59$

Dealing with or treating or both? 60

Obsessional traits $\quad 61$

Anxiety states 64

Dealing with anxiety $\quad 65$

Manic states $\quad 66$

Dealing with mania $\quad 66$

Neurological/organic/toxic states $\quad 67$

$\begin{array}{ll}\text { Schizophrenia } & 67\end{array}$

$\begin{array}{ll}\text { The fear of mental illness } & 70\end{array}$

It's physical - not mental $\quad 70$

Handicap - the best excuse of all 72

Labelling $\quad 72$

Handicap $\quad 73$

Behaviour $\quad 73$

Jargon $\quad 73$

Is it really necessary? 
The value of jargon and labelling 75

Recording, monitoring, charting

Assessment

Case notes

Negative reports

Assessing what?

81

Recording

The best place to be

Moving out

84

Staying put

85

Mismanagement

To tell or not to tell

Support systems

Counselling

Who needs friends?

Gaining confidence

4 Halfway There: A Conclusion So Far

5 Building Relationships

Observation

The approach

Getting close

Doing nothing

6 Being Practical

Using sounds

Using tape recorders

Flexibility

Smells and smells

Hair

Soap

Bath time

Talcum powder

Scent and aftershave

Hand cream and body lotion

Feet

Getting down to basics 
It's tasty

One lump or two?

Variety

7 Being Realistic

Movement

Rationale

Think before you speak

Keep it simple

Getting wet

Hydrotherapy

Swimming pools

Cost

Transport

123

Help!

124

Plan of action

124

Homework

124

Once there

Specific problems $\quad 128$

Golden rules

Water play

One to one

Advantages of water play

Disadvantages

Points to remember

Yawn, yawn - boring, boring

8 Being Creative

The abuse of music

Triangles, finger bells and bells 134

Percussion $\quad 135$

Musical variety $\quad 135$

Painting

Be adventurous but realistic

Mess is inevitable

Choosing materials

Brushes

Alternatives

Body paints

Seeing and hearing painting 
Blowing paint

Ideas to get you going

140

Table-top painting

Sensory painting

141

141

Net curtains

141

142

Kitchen gloves

142

Tin foil

142

Glue

143

From the garden

143

Material

143

Corrugated cardboard, rubber and paper $\quad 143$

Stencils

144

145

Sand

145

Feeling sand

145

Now you see it - now you don't

145

Wet sand

145

Sand for all

146

Working with clay

Back to nature

Getting started

148

A simple guideline

9 How About ... ?

Outings

Photographs

152

Pets

154

Story telling

155

Massage

Volunteers

10 The Final Word

Out of space

Conclusion

Appendix 1 : Interesting Reading

Appendix 3: The Profound Retardation and Multiple Handicap Project

Appendix 4: Reference Reading for Historical 


\section{Foreword}

When asked to read the first draft of this book, I approached it with caution: having worked in the field of handicap for many years, was yet another expert going to tell us lesser mortals what to do? I was amply reassured. Pat Brudenell has brought together a book that explores with us the problems concerning profound mental handicap, rather than talking at us. Based on the author's own lengthy experience, we are guided through the important basic areas that all of us, professionals, parents and volunteers, need to address if we are to maximise our own potential and the potential of those with whom we work.

The book starts by putting the problems of mental handicap into a historical perspective from the Middle Ages until now, and pointing out the appalling conditions that so many disabled people had to live in, including total non-differentiation between themselves and people who were also mentally ill. The information on the legal aspects of handicap are clear and at times appalling: I had to remember that it was not until 1983 that the phrase 'educationally subnormal' was replaced by 'children with learning difficulties'. A very comprehensive section on the family deals realistically with so many issues besetting the family who have a handicapped child. The case histories are clear and helpful and point out how much more strain families of handicapped children have. There are various suggestions on helping with this, one of which I should mention: why must we all assume that the parents of a handicapped child necessarily want to spend all their spare time with other parents of handicapped children?

The book goes on to discuss the importance of professional staffing for Special Care Units. It is easy for this area to 
attract less qualified staff because it is so often considered the Cinderella of the professions. Untrained staff are not dismissed - they have a valuable part to play in a total care programme. But what about staff support? Pat Brudenell makes the strong plea that staff working under such demands and in Units that are so often very isolated need a very strong support system.

The material on assessment and recording of progress is well described and most useful. We are then introduced to very basic, clear ideas in play, movement, art and music. The practical examples are most appropriate and will give heart to the most jaded worker. Often staff forget that creative ideas do work and regard structured rote learning as the only approach to the education of handicapped people.

Pat Brudenell brings a wealth of ideas to this subject. Her own zest for living and working is apparent throughout the book. There are some delightful glimpses of the author herself. For example, she says: 'I have always had a bit of a soft spot for manic patients .... There is something quite splendid about feeling on top of the world.'

This book is both optimistic about mentally handicapped people in the 1980s and also realistic. No one will get false hope through this material. Rather I would describe it as creative realism with a lot of humanity! A pertinent example of the human side of the book is the somewhat chaste reminder to get out of our stereotyped ideas about presents we might buy for mentally handicapped people. Have we ever thought of 'buying a little luxury'?

I warmly recommend this book to all those working with profoundly handicapped people. I know they will find it both stimulating and supportive.

Hertfordshire, 1985

Sue Jennings, FRAI, RDTh, Dip Soc Anthrop, LRAM, LGSM Senior Lecturer and Course Leader Hertfordshire College of Art and Design and Director, Dramatherapy Consultants 


\section{Preface}

The 'New Approaches to Care' series looks at the other side of caring for a wide variety of people and patients of all ages. As part of the series, this book is primarily concerned with the care of the profoundly handicapped child and adult. Although much has been written about handicap, there has been very little written about profound mental handicap. Not having the benefits of being able to read about the experiences of others working in this field has made the task of developing new ideas all the more difficult. For myself, arriving at the point whereby I began to understand what profound handicap actually meant personally, enabled me to be far more receptive and resourceful in terms of what $I$ was then able to do. If I can convey even a small part of this, then this book will have been worth while.

The idea stems from my own personal enjoyment and frustration of working in a Special Care Unit and with people with very special needs and is very much a personal statement. My rationale, interpretations and case studies are based upon my own experiences with my own groups. I have changed names and circumstances to protect the privacy and confidentiality that was entrusted to me. The views and attitudes expressed by parents are representative of those parents I interviewed. They may not be relevant to all family situations but they are nevertheless true of their own. I hope the reader will be able to relate to the various standpoints, as a parent, as a practitioner, as a friend or simply as an interested party.

I have deliberately kept off issues of benefits, equipment and theories as these areas and many more have been capably dealt with by other authors. There is little reference to specific diagnosis as I have tried to convey the entirety of handicap - 
incorporating the whole person - bringing in aspects that go beyond the handicap itself.

Profoundly handicapped people are entirely dependent on others for all their needs. They can only rely on the voices of those around them to improve their quality of life, raise the standards of their care and protect their human and civil rights. The severity of their handicap prevents them from telling their own story. I only hope that my interpretations are somewhere near to their truth.

Harrow, 1985

P. B.

$N$. B. The views and opinions expressed in this book are personal to the author and are not reflective of the authority by whom she is employed. 


\section{Acknowledgements}

Without the tremendous support and encouragement of so many people, this book would never have been written. My grateful thanks are given to all those who have knowingly and unknowingly contributed, but with special mention to the following:

To John Crowson for his patience in not only being able to capture a photographic record of my work but for his patience with me.

To friends and ex-colleagues - Sue, Jenny, Penny and Jenny. Their enthusiasm kept me going when the going got tough.

Special thanks to Pat Mickleburgh for her secretarial assistance and patience with the first draft.

To Sandi Hammond, for hours spent on the personal computer deciphering the final draft, but most especially for her tremendous support throughout the final stages. To her, my very special and heartfelt thanks.

To Printronic Corporation (UK) Ltd. I am indebted to the company for allowing me access to their technology, which assisted me enormously in the compilation of the final draft.

To friends who urged me to make a start, but especially to Jennifer. Her advice and guidance and share of the anguish and excitement of writing my first book tested friendship to the limits and beyond. To her, my very special thanks.

Mention must be made to the families I worked with and of course to their youngsters, who feature largely throughout the book. For allowing me the opportunity to see handicap from another angle and for teaching me so much, I am very grateful. 
To Sue Jennings, for not only agreeing to write the foreword but for being both tutor and friend. She has played a major role in my development as a therapist, and it was with her guidance and support that I was able to make the move to work with mentally handicapped people. For this and much more, my grateful thanks.

Finally to Robert. Throughout the chaos that this book has brought to our home, he has managed to hold onto his sense of humour and shared most of the traumas with a smile. To him, my very special thanks. 